\title{
Identifying integrated options for agricultural climate change mitigation
}

\section{Author biographies:}

Dr John Tzilivakis BSc MSc PhD AIEMA, Agriculture and Environment Research Unit (AERU), School of Life and Medical Sciences, University of Hertfordshire, UK. John has worked for AERU since its foundation in 1995. He has worked on numerous projects for the European Commission, UK government and the agricultural industry, related to agriculture, the environment and sustainability. This has included the development of carbon footprinting tools, as well as evaluating the environmental benefits of farming systems, farm assurance and environmental labelling standards. Other work has focused on the development of various software applications for farmers and policy makers across Europe.

Dr Kathleen A. Lewis BSc PhD MIEMA FIAP, Agriculture and Environment Research Unit (AERU), School of Life and Medical Sciences, University of Hertfordshire, UK. Kathy is the research leader for AERU, which she founded in 1995. She has worked on numerous projects for the European Commission, UK government and the agricultural industry. Her work covers a wide range of environmental issues within agriculture and horticulture, specialising in taking a whole-farm perspective. She is involved in the development of techniques to encourage sustainable agriculture, including its socio-economic aspects, rural development and policy issues.

Dr Andrew Green BSc MSc PhD AIEMA, Agriculture and Environment Research Unit (AERU), School of Life and Medical Sciences, University of Hertfordshire, UK. Andy has worked for AERU since 2000. He has worked on a wide range of projects for the European Commission, UK government, environmental groups and the agricultural industry, from both a policy and farm management perspective; including work on the environmental labelling of food, agricultural pollution and its mitigation, the international delivery of environmental data and holistic sustainability.

Dr Douglas J. Warner BSc MSc PhD AIEMA, Agriculture and Environment Research Unit (AERU), School of Life and Medical Sciences, University of Hertfordshire, UK. Doug has worked for AERU since 2001. He has worked on numerous projects for the European Commission, UK government and the agricultural industry, related to climate change mitigation, biodiversity and farmland conservation, integrated crop management, organic farming, bio-control of pests, and livestock systems.

\subsection{Introduction}

\subsection{Background}

The change in atmospheric concentrations of greenhouse gases (GHGs), due to anthropogenic emissions, and the impacts on climate are issues that have risen up the societal agenda in recent decades. Although there are uncertainties associated with the science of climate change, the evidence suggests that we should act now to reduce GHG emissions as part of broader efforts to encourage sustainable development (Defra, 2005; Stern, 2006). Some agreements are already in place to help tackle this issue. For example, the Kyoto Protocol (UN, 1998) has committed industrialised nations to a reduction in GHG emissions (in particular carbon dioxide $\left(\mathrm{CO}_{2}\right)$ ) of $5.2 \%$ below their 1990 levels during the first commitment period (the Quantified Emission Limitation or Reduction Commitments (QELRC)) between 2008 and 2012. The EU is required to collectively reduce GHG emissions by $8 \%$ and individual Member States have committed to further reductions.

In order to achieve these reductions it is essential that all industry sectors, and society as a whole, have the appropriate knowledge, tools and advice on how to reduce or mitigate GHG emissions. This includes agriculture, which is considered to contribute $8.6 \%$ emissions in the UK (DECC, 2012), 9\% in Europe (European Commission, 2009) and about a third of emissions globally (Solomon et al., 2007; Harvey and Pilgrim, 2010), largely from nitrous oxide $\left(\mathrm{N}_{2} \mathrm{O}\right)$, 
methane $\left(\mathrm{CH}_{4}\right)$ and carbon dioxide $\left(\mathrm{CO}_{2}\right)$. There is scope to reduce agricultural emissions and there may also be potential to sequester carbon into the soil and vegetation, thus helping to reduce atmospheric concentrations of $\mathrm{CO}_{2}$. The figures for potential carbon sequestration are subject to significant uncertainties (Dawson and Smith, 2007; King et al., 2004; Ostle et al., 2009) and there is a finite capacity for sequestration, i.e. where the soil reaches equilibrium and no more carbon can be sequestered (Johnston, 2008). However, the potential for sequestering carbon should not be overlooked because of these uncertainties and in many instances there are synergies with other environmental benefits, such as improved soil quality. This highlights an important issue in that the GHG emissions and carbon sequestration are only two issues out of many that need to be tackled by the agricultural industry. Agriculture is often referred to as being multi-functional (Renting et al., 2009; Van Huylenbroeck and Durand, 2003) with respect to the 'goods and services' it should provide. As well as producing food, fibre, oils and biomass to equitably meet the needs of an increasing global population, it must also function as a habitat for biodiversity, a buffer and filter for pollutants and satisfy the demands of society in terms of the landscape it creates and any environmental pollution or damage it causes. Consequently sustainable agriculture is about finding a balance between environmental, economic and social objectives, and not pursuing a single objective (e.g. climate change mitigation) in isolation from other objectives. Finding this balance is not easy as agricultural production systems are complex and dynamic. There are flows of materials and energy on and off farms and a change in one part of system can have consequences in another part. Consequently Life Cycle Thinking (Brentrup, et al., 2004) is required - sustainable solutions require holistic thinking. However, the scope for complexity is large, especially when consideration is given to the diversity of farming systems across the EU, activities on farms, the materials and energy they utilise and how this is interwoven with a range of habitats, biodiversity and environmental media. The potential environmental effects are numerous and can have a range of direct and indirect impacts, both positive and negative (Girardin et al., 2000; Petchey et al., 1995; Pretty et al., 2000 and 2005; Skinner et al., 1997; Watkiss, 2009; Withers and Lord, 2002).

\subsection{Carbon calculators}

The starting point for identifying opportunities for GHG mitigation is for a business to quantify GHG emissions and to identify their source. Carbon accounting (or carbon footprinting) techniques are often used for this purpose. This approach is historically associated with Life Cycle Assessment (LCA) and estimates the amount of GHG emissions produced during a defined time period expressed in carbon dioxide equivalents $\left(\mathrm{CO}_{2} \mathrm{e}\right)$ which, as well as carbon dioxide $\left(\mathrm{CO}_{2}\right)$, includes emissions of methane $\left(\mathrm{CH}_{4}\right)$ and nitrous oxide $\left(\mathrm{N}_{2} \mathrm{O}\right)$ (Smith et al., 2008). Within LCA the net $\mathrm{CO}_{2} \mathrm{e}$ (the total GHG emissions minus carbon that sequestered or offset) is an LCA mid-point pressure indicator which can then be used to estimate Global Warming Potential (GWP) - an LCA impact category. Due to increasing use of this indicator, and the need to compare values across organisations and processes, two broadly similar standards are now publically available: PAS2050 (BSI, 2008) and the GHG Protocol Product Standard (WRI, 2011). These seek to provide transparent and robust frameworks for measuring GHG emissions.

In recent years there have been many carbon calculators developed which conform to these standards. Currently, there are four main tools in common use that are suitable for European farming and which address both emissions and carbon sequestration. CPLAN (CPLAN, 2012) is available in a variety of versions, all are web-based, have low input data needs and the simplest version is free to use. CALM (CLA, 2012) has been developed by the Country Land and Business Association and is slightly more complex than CPLAN but very similar in that it is also free to use, web-based and has low data demands. CCaLC (CCaLC, 2011) and COOL (Hillier et al., 2011) are more comprehensive in the farming activities covered and both have been developed using MS Excel. This spreadsheet approach offers advantages and disadvantages. On the plus side many users will be familiar with Excel and its embedded facilities. However, the complexity of farming systems generally means that the spreadsheets are multi-layered, complicated, and, as a consequence, are cumbersome to use. Whilst COOL is specifically a farm based tool, CCaLC has been designed for supply chain analysis. The latter can, however, be used for farm enterprises by selecting just that process unit. 
Other tools are also available but they tend to have a more limited application. For example, Carbon Friendly Food (CFF, 2010) promotes a calculator designed specifically for organic production, there is also one specifically for biofuel production (HGCA, 2006) and the CometVR tool focuses just on carbon sequestration (NRCS, 2007). Similar tools are also beginning to emerge in other countries such as that developed by McPhee et al. (2010) which is aimed towards Australian land managers and another is now available in France (Solagro, 2012) which uses the spreadsheet approach.

These carbon accounting tools can be used in a number of ways to help manage GHG emissions. In their simplest role they can be used to raise awareness and to educate. However, just knowing the quantity of emissions is not particularly valuable unless action is taken to reduce them and so, to be useful, the tools must be able to identify where a pragmatic change in farm practices can lead to a cost-effective reduction in emissions. All of the tools mentioned here claim they can be used for identifying GHG mitigation options. In practice this is achieved by the end user exploring what-if scenarios and varying input parameters. Therefore the opportunities for identifying mitigation options will depend entirely on the range of farming activities included within the tool. For example, there is potential for livestock farmers to reduce GHG emissions via dietary manipulation (e.g. Tedeschi et al., 2003; McGuffey et al., 2001). These opportunities can only be explored within the tool if appropriate data on livestock feeds are included. Similarly, unless cost information is included along with data on other environmental impacts these issues must also be explored independently. Therefore, in order to be useful in the wider context of sustainability, such tools must be capable of coping with the wide variety of site and business specific properties which can influence the quantities of GHGs lost (Hillier et al., 2011) and sound business decisions to be made.

\subsection{The IMPACCT model}

This paper reports on a model known as IMPACCT, which stands for 'Integrated Management oPtions for Agricultural Climate Change miTigation', that was developed for the European Commission as part of a broader study entitled "The climate change mitigation potential of an EU farm: towards a farm-based integrated assessment". Although the main focus of this model is on greenhouse gas emissions, carbon sequestration and associated mitigation options, it has also attempted to include information on economic and other environmental impacts in order to provide a more holistic and integrated perspective, tackling many of the issues outlined above. The model was designed for use on farms by farmers and their advisers, but it does have potentially wider applications and users include those formulating policy or those exploring supply chain impacts, who wish to explore potential issues and options at the farm level. This paper outlines the broad scientific approach taken to the development of the model, especially in relation to the pragmatic delivery of integrated mitigation options on farms, thus encompassing issues of scientific knowledge transfer as well as the science itself.

The description of the model is broken down into four sections:

1. The core database: Its design and structure

2. The data: The different types of information stored in the core database and how it was gathered and generated.

3. The calculation and assessment processes: The calculations and processes involved in assessing GHG emissions and identifying mitigation options

4. The IMPACCT software: The delivery vehicle for the model, including some examples of its application. 


\subsection{The core database: design and structure}

At the heart of the model is a core database that contains details emissions of greenhouse gases, carbon sequestration, other environmental impacts and economic information. The database is structured using three main elements:

1. Farm components

2. Modifiers

3. Activity data items

\subsection{Farm components}

Farm components have a three tier structure consisting of Enterprises, Parent components and Child components. A number of existing farm typologies were reviewed as part of the study and the EU typology (European Commission, 1985) was selected as a structure for the Enterprises used within the model. Thirty enterprises have been mapped to the 'particular', 'principal' and 'general' farm types. Each Enterprise has been broken down in Parent components and each Parent component has been broken down into Child components. This structure is illustrated below for the Enterprise 'Dairy (milk)':

- Dairy (milk)

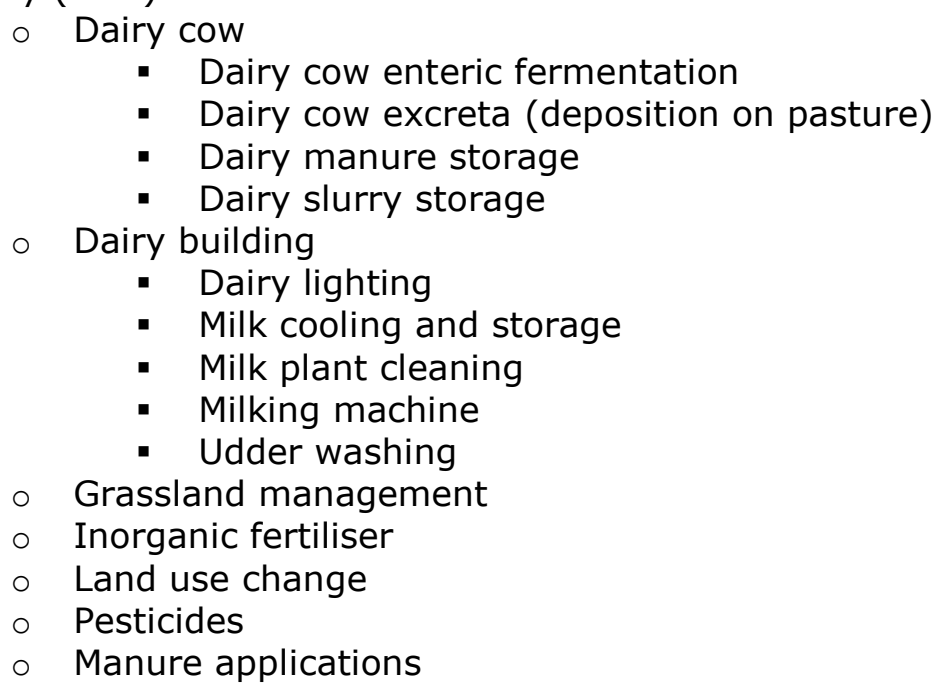

Farm components are not just GHG emissions sources. Carbon sequestration, other impact data and GHG emissions are all stored against the child components. This parent-child structure allows data to be aggregated and presented in a simpler format when undertaking assessments. It also facilitates the allocation of emissions and other impacts to different enterprises on a farm, as this can be a common problem in multi-functional systems (Cederberg and Stadig, 2003).

\subsection{Modifiers}

For each component there are variable emissions, sequestration and other impact factors. The variations in the data are determined by the 'modifiers'. For example, the component 'Dairy cow enteric fermentation' has the following modifiers (and modifier classes): 'Dairy cow improved breed' (Yes/No); 'Dairy cow dietary additives used' (Yes/No); and 'Dairy cow diet' (12 different types of diet). These combinations result in 48 different emission factors for this component, thus what the user selects (in relation to the farm practices) when undertaking their assessment will determine what emission, sequestration or other impact factors are used in the calculations.

Modifiers are split into Fixed and Variable modifiers. Fixed modifiers are those factors which are generally not within the control of the farm but which will determine differences in emissions, sequestration and other impacts, for example climate and soil type. Variable 
modifiers are those factors which are within the control of the farm, and consequently consist of practices and infrastructure that can be changed, for example livestock diet, types of machinery and fertiliser practices. As such variable modifiers also make up many of the mitigation options that are presented to the user as part of the assessment. There are currently 113 variable modifiers and 316 modifier classes, thus providing a range of potential mitigation options.

\subsection{Activity data items}

These are quantifiable pieces of information about the farm that are used to 'multiply' up emissions and other data retrieved from the core database (e.g. numbers of cattle or amount of fertiliser used), thus helping to identify the most significant emission sources of the farm. Some data items also have economic information attached to them, e.g. to indicate potential impacts on output, should the quantities be altered as part of a mitigation strategy.

\subsection{The data}

\subsection{GHG emissions and carbon sequestration}

Data on GHG emissions and carbon sequestration have been gathered from a broad range of sources (over 50 sources, all fully referenced within the core database) in order to populate the core database using the component-modifier structure described above. In many instances meta-modelling has also been undertaken in order to derive more responsive emission factors, i.e. those which change according to the situation of the farm and the practices adopted (the fixed and variable modifiers). For example, the IPCC (2006) methodology uses default values for calculating $\mathrm{N}_{2} \mathrm{O}$ emissions in the absence of national or regional data (Tier 1 approach) but recommends incorporation of national data if available (Tier 2 or 3 approach). The Tier 1 approach has been criticised for the over-estimation and under-estimation of soil $\mathrm{N}_{2} \mathrm{O}$ emissions depending on soil conditions (Dobbie and Smith, 2003). Therefore, where relevant, meta-modelling with available decision support tools has been undertaken to derive practice responsive and more accurate emission factors. Table 1 lists the models that have been used to help populate the core database.

Table 1: Models used to help populate the database

\begin{tabular}{|l|l|l|}
\hline Model name & Description & References \\
\hline IPCC & $\begin{array}{l}\text { Methodology for } \mathrm{CH}_{4} \text { and } \mathrm{N}_{2} \mathrm{O} \text { from different manure } \\
\text { storage techniques and at different temperatures }\end{array}$ & IPCC (2006) \\
\hline SUNDIAL & $\begin{array}{l}\text { Simulates denitrification, nitrification, volatilisation } \\
\text { and N leached in response to soil type, daily rainfall, } \\
\text { temperature and evapotranspiration }\end{array}$ & Smith et al., 1996 \\
\hline MANNER & $\begin{array}{l}\text { Provides output of leaching and volatilization from } \\
\text { field application of livestock manures. It accounts } \\
\text { for manure type, alteration to application method, } \\
\text { previous storage, soil type, timing and excess } \\
\text { winter rainfall. }\end{array}$ & Chambers et al., 1999 \\
\hline FiM & $\begin{array}{l}\text { (Feed into Milk): GHG calculator for forage and } \\
\text { concentrate crops used on dairy farms. }\end{array}$ & Thomas, 2004 \\
\hline GREENERGY & $\begin{array}{l}\text { (Energy optimization in greenhouses): models } \\
\text { energy consumption in glasshouses for a variety of } \\
\text { crops, structural modifications and modifications to } \\
\text { management (humidity and temperature set- } \\
\text { points). }\end{array}$ & $\begin{array}{l}\text { GREENERGY, 2008; } \\
\text { Korner et al., 2007 }\end{array}$ \\
\hline ISO 205 & $\begin{array}{l}\text { Calculates enteric methane values based on the } \\
\text { proportion of concentrates and forage }\end{array}$ & $\begin{array}{l}\text { Williams et al., 2009; } \\
\text { Williams et al., 2006 }\end{array}$ \\
\hline
\end{tabular}




\subsection{Other environmental impacts}

As described above, GHG emissions and carbon sequestration are not the only environmental issues associated with agricultural production. A review was undertaken as part of the work for the European Commission, to identify key environmental impacts, especially those related to practices which also impact upon greenhouse gas emissions. This review covered a range of issues including air quality, soil quality, water quality, biodiversity, stratospheric ozone depletion, resource use, waste and recycling, landscape and heritage and public safety and nuisance. A taxonomy based on environmental and socio-economic outcomes (Tzilivakis et al., 2009; Tzilivakis et al., 2011) was drawn upon within the model to provide a range of standard environmental impact categories. There are two levels to this taxonomy, desirable outcomes and outcome groups. There are 64 desirable outcomes (including reducing GHG emissions and increasing carbon sequestration) which are grouped together into 18 outcome groups. Half of these (see Table 2), that relate to environmental outcomes, form the impact category structure used in IMPACCT.

\section{Table 2: Environmental impact categories (outcome groups)}

\begin{tabular}{|l|l|}
\hline \multicolumn{2}{|c|}{ Impact categories } \\
\hline Air quality & Energy \\
\hline Biodiversity & Greenhouse gas emissions* \\
\hline Carbon sequestration* & Landscape and heritage \\
\hline Countryside access and recreation & Soil quality \\
\hline Efficient use of resources & Water quality \\
\hline
\end{tabular}

* Quantified in IMPACCT

A scoring system of +10 to -10 was used to reflect positive and negative environmental impacts. The scores are based on expert judgement and are used to reflect potential changes in impact, rather than reflect scale or magnitude of the impact. The model calculates a score for each 'other impact' associated with each potential GHG mitigation option for a farm. This 'other impact' score is then compared to the current (baseline) situation for the farm. The difference in the impact score is then reported alongside the GHG mitigation potential and consequently users can see if there is a net increase or decrease in any 'other impacts' and this determines synergies and trade-offs - thus providing an integrated perspective.

In theory it would be possible to quantify some of the impacts in the same way as GHG emissions, for example losses of nutrients or pesticides to ground and surface water. The same database structure could be applied to these issues. However, this would require significant work to implement (and was beyond the scope of the project) and would also require more computing power to run the model.

\subsection{Data quality}

The data used to populate the core database varies in quality with respect to the level evidence supporting it and the reliability of the source. This is inevitable as data on emissions, sequestration and other impacts does not all come from one source. It is important that end users of the model are aware of this variability in the quality of the data, so that it can be taken into account in any decisions being made. For example, if an option is presented that has high mitigation potential, but is expensive to implement, then it is important to know the quality of the evidence on which it is based. If the data quality is low, then this may not be satisfactory on which to base a high cost decision. To tackle this issue a 'quality barometer' (Lewis et al., 2003; Lewis et al., 2007) has been developed and is used within the model.

Each item of data in the core database has a corresponding field to hold a data quality score. This score ranges from 0 to 5 , where 1 is low and 5 is high. The score is awarded using expert judgement and based on the quality of the evidence supporting the data as shown in Table 3. For example, 5 would be well established data supported by numerous empirical studies, whereas 1 might be anecdotal information or single one off studies that have not been replicated. Other issues may also exist that can shift the data quality barometer score down. 
For example if data is from a respected source (i.e. a quality score of 4 or 5 ) but there are doubts about the data set due to monitoring issues, for example, then the barometer score might be reduced further (i.e. to a 3 or 4 ).

Table 3: Rules for assigning data quality scores needs

\begin{tabular}{|l|l|}
\hline Quality Score & Guideline \\
\hline $\mathbf{4}$ or $\mathbf{5}$ & $\begin{array}{l}\bullet \text { there is ample, well documented evidence in peer reviewed scientific } \\
\text { and/or best practice literature supporting the data; } \\
\text { data are useable in its published format; } \\
\text { data are from a recognised and respected source such as a government } \\
\text { department. }\end{array}$ \\
\hline $\mathbf{3}$ or $\mathbf{4}$ & $\begin{array}{l}\text { there is some documented evidence in peer reviewed scientific and/or } \\
\text { best practice literature supporting the data; } \\
\text { data has been generated using well recognised and accepted } \\
\text { mathematical models (meta-modelling approach); } \\
\text { - } \begin{array}{l}\text { whilst the data is high quality, it requires some conversion or } \\
\text { adjustment before it can be used in the model. }\end{array}\end{array}$ \\
\hline $\mathbf{2}$ or $\mathbf{3}$ & $\begin{array}{l}\text { there is limited documented evidence in support of the data; } \\
\text { models used to generate the data are not widely used or recognised as } \\
\text { having limitations; } \\
\text { data source is not well known. }\end{array}$ \\
\hline $\mathbf{1}$ or $\mathbf{0}$ anecdotal evidence; \\
expert judgement; \\
unknown or unverified source.
\end{tabular}

Numerical data quality scores are not displayed to the end user. Instead a data quality graphic (see Figure 1) is used (similar to the signal strength indicator used on some mobile phones or wireless networks) to reflect the relative 'strength/quality' of the data. This helps reduce the amount of numerical data that are displayed within the assessment results, so that the user is not 'overloaded' with numbers, thus aiding interpretation of the results.

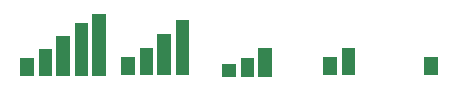

Figure 1: Data quality indicator graphics (high to low)

It should be noted that the data quality score is a reflection of the attributes of the source of the data and does not necessarily represent the uncertainty. Some aspects, such as carbon sequestration, are currently inherently uncertain (Dawson and Smith, 2007; King et al., 2004; Ostle et al., 2009) and a range of values can exist for certain parameters. This is not necessarily reflected in the data quality score. It will have been taken into account, but what should be done would be to include the range of data (e.g. from best to worse case) and store this within the core database and then allow the model to draw upon these figures to express a range within the end results.

\subsection{Economic information}

The database is designed to handle economic data using the same component-modifier structure as emissions and sequestration data. However, the economic data suffered with a number of problems which meant it could not be structured in this way. The problems included:

- Economic data being more qualitative and scarce

- Data being highly situation unique

- Placing economic figures in context across the whole of the EU was problematic

- Prone to change (often in very short time frames), leading to updating issues 
As a consequence an alternative approach to storing and structuring economic information was developed. The approach involves scoring the relative annual and/or capital cost for each modifier class on a scale of 0 to 5 . This score can then be used to highlight to end users when there may be significant capital costs involved with a mitigation option and/or what the change in annual cost might be. This score is also accompanied with economic information/statements to provide further information on the economics, for example the installation of a biogas/anaerobic digestion plant has the following statements attached to it:

- Anaerobic digestion or biogas plants can be very expensive to construct (e.g. €200K $€ 2$ million depending on size).

- Grants are available in some countries to cover capital costs.

- Methane from biogas plants can be used a source of fuel on farms.

Some 'Activity data items' also have economic information attached to them, e.g. to indicate potential impacts on output, should the quantities be altered as part of a mitigation strategy. For example, reducing dairy cattle numbers may reduce emissions but could also reduce milk production, unless production efficiency is increased.

\subsection{The calculation and assessment processes}

The calculations within the model are relatively simple. In most instances a combination of modifiers (see Section 3.2) are used retrieve an emissions factor or impact score from the core database for a component. Table 4 shows a simple example for short-term fruit storage, based on data from CALU (2007) and Milà i Canals et al. (2007). This data is then multiplied up by the relevant activity data entered by the user (in the example shown in Table 4 this would be tonnes of fruit stored). All emissions are calculated for the original greenhouse gas if an emission factor for a specific gas exists, if not then a $\mathrm{tCO}_{2} \mathrm{e}$ factor us used. Resulting emissions data for the whole farm are shown as $\mathrm{tCO}_{2} \mathrm{e}$ using $\mathrm{GWP}_{100}$ equivalency factors (these can be set in the software settings, but by default are 25 for $\mathrm{CH}_{4}$ and 298 for $\mathrm{N}_{2} \mathrm{O}$ ). The user can 'drill down' to the details of individual gases on the report screen. All the underlying emission factors used in the model are available to be viewed, along with reference sources, in the toolbox section of the IMPACCT software.

Table 4: Example emissions data for short-term fruit storage

\begin{tabular}{|c|c|c|c|}
\hline \multicolumn{2}{|c|}{ Modifiers } & \multirow{2}{*}{$\begin{array}{c}\mathbf{t C O}_{\mathbf{2}} \mathbf{e} / \text { tonne of } \\
\text { fruit/year }\end{array}$} \\
\hline Energy/fuel source & $\begin{array}{c}\text { Use air curtains / } \\
\text { flexible doors }\end{array}$ & $\begin{array}{c}\text { Use forced } \\
\text { ventilation }\end{array}$ & 0.00065 \\
\hline UK Grid electricity & No & No & 0.00060 \\
\hline UK Grid electricity & No & Yes & 0.00064 \\
\hline UK Grid electricity & Yes & No & 0.00059 \\
\hline UK Grid electricity & Yes & Yes & 0.00037 \\
\hline Gas/diesel oil & No & No & 0.00035 \\
\hline Gas/diesel oil & No & Yes & 0.00037 \\
\hline Gas/diesel oil & Yes & No & 0.00034 \\
\hline Gas/diesel oil & Yes & Yes & \\
\hline
\end{tabular}

For carbon sequestration in the soil an additional calculation is undertaken to determine the number of years for which sequestration can occur before equilibrium is reached. In this instance the potential maximum carbon that can be stored for the given conditions, e.g. soil type and/or land use, is divided by the annual sequestration rate for the specific practice/component. This then determines the number of years for which sequestration can occur till equilibrium is reached. This is important as it not possible to endlessly sequester carbon into the ground, and a point will be reached where any additional carbon (e.g. applied as manure) may be lost to the atmosphere. One limitation of the calculation in the model is that ideally the current carbon stock in the soil should be taken into account when determining how many years sequestration potential there is (how much carbon may be added to the soil if a change in land use or land management within a given land use is undertaken). If the soil 
organic carbon (SOC) is already at, or close to, its maximum at equilibrium, then the quantity of $C$ that may be added is limited and the number of years where accumulation may result due to a change in management will be lower. The model currently assumes the mean value for SOC for a given soil type and land use (Dyson et al., 2009) but it is acknowledged that it may be higher or lower depending on the previous management history of that particular land use. The exact SOC of a soil is difficult to predict without direct measurement.

Given the above structure and data, users can select farm components, the modifiers that apply to those components and then enter the necessary activity data for the calculations. The software then calculates the emissions, sequestration and other impacts for items selected and data entered by the user. The software automatically interrogates the database to determine what modifiers, i.e. alternative practices (for the components selected), would result in emissions reduction and calculates what the reduction would be and if there are any associated other impacts. The resulting potential mitigation options are then presented to the user, along with any potential other impacts and potential economic burdens or benefits - thus allowing the user to make a cost-benefit decision with respect to what mitigation options they could implement to help reduce greenhouse gas emissions.

\subsection{The IMPACCT software}

The IMPACCT software is the delivery vehicle for the model. It is prototype software developed using MS Visual Basic 6 for the user interface and MS Access for the core database. The software is installed and runs locally on users PC, with updates available from a web server. The software is currently freely and publicly available to download from the IMPACCT website (see http://www.herts.ac.uk/aeru/impacct/).

The farm assessment allows user to create descriptions of a farm, calculate the emissions and sequestration profile for that farm, identify potential mitigation options to reduce emissions and any associated other environmental or economic impacts, and allow the user to select and implement those options to observe what impact this has on their emissions profile. This process is illustrated below using case study farm.

The farm is in France with 138 dairy cattle, 73 ha of barley, 50 ha of oilseed rape, 14 ha of triticale and 117 ha of wheat. The user enters these details along with other details on the practices employed and quantities used and then the software can calculate the emissions profile for the farm and identify any potential mitigation options. The emission profile is summarised in Tables 5 and 6, and Table 7 shows a summary of the suggested mitigation options.

Table 5: Results summary: emissions per output

\begin{tabular}{|l|l|l|l|}
\hline Output & Quantity & Emissions & Sequestration \\
\hline Wheat & 1053 Tonnes & $0.008 \mathrm{tCO}_{2} \mathrm{e}$ per tonne & $0.012 \mathrm{tCO}_{2}$ per tonne \\
\hline Barley & 606 Tonnes & $0.183 \mathrm{tCO}_{2} \mathrm{e}$ per tonne & $0.02 \mathrm{tCO}_{2}$ per tonne \\
\hline Triticale & 98 Tonnes & $0.254 \mathrm{tCO}_{2} \mathrm{e}$ per tonne & $0.124 \mathrm{tCO}_{2}$ per tonne \\
\hline Oilseed rape & 175 Tonnes & $0.684 \mathrm{tCO}_{2} \mathrm{e}$ per tonne & $0.07 \mathrm{tCO}_{2}$ per tonne \\
\hline Milk & $\begin{array}{l}\text { 1311 Thousand litres } \\
\text { (farm total) }\end{array}$ & $\begin{array}{l}0.345 \mathrm{tCO}_{2} \mathrm{e} \text { per thousand } \\
\text { litres }\end{array}$ & $\begin{array}{l}\mathrm{tCO}_{2} \text { per thousand } \\
\text { litres }\end{array}$ \\
\hline
\end{tabular}


Table 6: Results summary: emissions by farm component

\begin{tabular}{|c|c|c|c|c|}
\hline Component & $\begin{array}{l}\mathrm{tCO}_{2} \mathrm{e} \\
\text { emissions }\end{array}$ & $\begin{array}{l}\mathrm{tCO}_{2} \\
\text { seq. }\end{array}$ & Other impacts & DQ \\
\hline Dairy cow & 441.16 & & $\begin{array}{l}\Delta \text { Potential negative impact on air } \\
\text { quality }(-1380)\end{array}$ & II \\
\hline $\begin{array}{l}\text { Inorganic fertiliser } \\
\text { (oilseed rape) }\end{array}$ & 108.33 & & $\begin{array}{l}\text { A Potential negative impact on } \\
\text { groundwater quality }(-18000)\end{array}$ & I \\
\hline $\begin{array}{l}\text { Inorganic fertiliser } \\
\text { (barley) }\end{array}$ & 96.42 & & $\begin{array}{l}\triangle \text { Potential negative impact on } \\
\text { groundwater quality }(-16000)\end{array}$ & II \\
\hline $\begin{array}{l}\text { Inorganic fertiliser } \\
\text { (triticale) }\end{array}$ & 24.09 & & $\begin{array}{l}\triangle \text { Potential negative impact on } \\
\text { groundwater quality }(-4000)\end{array}$ & II \\
\hline Dairy building & 12.88 & & & lll \\
\hline $\begin{array}{l}\text { Seedbed } \\
\text { preparation/soil } \\
\text { management } \\
\text { (barley) }\end{array}$ & 9 & & & 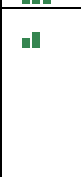 \\
\hline $\begin{array}{l}\text { Seedbed } \\
\text { preparation/soil } \\
\text { management } \\
\text { (oilseed rape) }\end{array}$ & 6.84 & & & II \\
\hline Harvesting (wheat) & 6.15 & & & nll \\
\hline Harvesting (barley) & 3.77 & & & الم - |ل \\
\hline Pesticides (wheat) & 2.45 & & & I \\
\hline $\begin{array}{l}\text { Harvesting (oilseed } \\
\text { rape) }\end{array}$ & 2.29 & & & all \\
\hline Pesticides (barley) & 2 & & & II \\
\hline $\begin{array}{l}\text { Pesticides (oilseed } \\
\text { rape) }\end{array}$ & 1.43 & & & II \\
\hline $\begin{array}{l}\text { Harvesting } \\
\text { (triticale) }\end{array}$ & 0.7 & & & inll \\
\hline Pesticides (triticale) & 0.13 & & & II \\
\hline $\begin{array}{l}\text { Environmental } \\
\text { features }\end{array}$ & 0 & $\begin{array}{l}48.73 \\
\text { for } 24 \\
\text { years }\end{array}$ & $\begin{array}{l}\text { Potential physical improvement to } \\
\text { soil ( } 77) \\
\text { Potential positive impact on } \\
\text { invertebrate populations ( } 33 \text { ) }\end{array}$ & 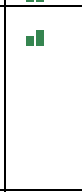 \\
\hline Total & 717.64 & 48.73 & & الـ \\
\hline
\end{tabular}

Icon key
$\triangle$ Potential negative environmental impact
Relative capital cost
Potential positive environmental impact
nll Data quality (DQ): Low • , Moderate nl , High nlll
Relative annual cost (benefit)
Relative annual cost (burden)

Table 6 shows that the biggest source of emissions on this farm is from dairy cows (from enteric fermentation and slurry and manure storage), followed by the use of inorganic fertiliser on barley and oilseed rape (with consequent other impacts associated with these).

Consequently the mitigation options (Table 7) with the greatest potential reductions focus on these components, namely the use of nitrification inhibitors, changing the dairy cow diet and the use of anaerobic digestion, and we can see there are consequent improvements to other impacts associated with these mitigation options. However, in the case of anaerobic digestion there are significant capital-costs involved, which may prevent this option being implemented. There are however, a number of other options to consider (see Table 7) which offer lower mitigation potential, but may be relatively low cost or even economically beneficial, largely through improved energy efficiency and thus reduced fuel costs. In combination, these could be almost equivalent to one of the options at the top of Table 7 (i.e. 5-6\% reduction). Table 6 also shows that the environmental features created on the farm (such as grass strips and hedgerows) are also contributing to carbon sequestration, but this is relatively small compared 
the total emissions and the annual rate of sequestration will only be maintained for approximately 24 years, at which point an equilibrium is reached (it should be noted that the data quality (DQ) is quite low for this calculation).

Table 7: Summary of suggested mitigation options

\begin{tabular}{|c|c|c|c|c|}
\hline Modification & $\begin{array}{c}\text { \% } \\
\text { reduction } \\
\text { of total } \\
\text { emissions }\end{array}$ & $\begin{array}{l}\text { Other impacts (net } \\
\text { change) }\end{array}$ & $\begin{array}{l}\text { Economic } \\
\text { information }\end{array}$ & $\mathbf{D Q}$ \\
\hline $\begin{array}{l}\text { Nitrification inhibitors used: } \\
\text { Yes }\end{array}$ & 10 & $\begin{array}{l}\text { Potential improvements } \\
\text { to groundwater quality } \\
(9000) \\
\text { Potential improvements } \\
\text { to groundwater quality } \\
(16000)\end{array}$ & $\sqrt{2}$ & II \\
\hline $\begin{array}{l}\text { Type of inorganic fertiliser: } \\
\text { Ammonium phosphate (18\% } \\
N ; 46 \% \text { P2O5) }\end{array}$ & 6.1 & & & ! \\
\hline $\begin{array}{l}\text { Dairy cow diet: J. } 1559 \mathrm{kgDM} \\
\text { grazing; } 390 \text { kgDM fodder } \\
\text { beet; } 2924 \text { kgDM maize silage; } \\
1914 \text { kgDM maize flaked }\end{array}$ & 5.5 & & & III \\
\hline $\begin{array}{l}\text { Dairy slurry store: Anaerobic } \\
\text { digestion }\end{array}$ & 8.5 & $\begin{array}{l}\text { Potential improvements } \\
\text { to air quality (1380) }\end{array}$ & & |lll \\
\hline $\begin{array}{l}\text { Types of harrow: Spring tine } \\
\text { harrows / weeding }\end{array}$ & 0.7 & & 5nd? & inll \\
\hline Types of harrow: Chain harrow & 0.7 & & mat & 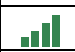 \\
\hline Rainfall forecasting used: Yes & 0.8 & & & $n$ \\
\hline Ploughing depth: $15 \mathrm{~cm}$ & 0.4 & & 3 & II \\
\hline $\begin{array}{l}\text { Overpowered tractor not used: } \\
\text { Yes }\end{array}$ & 0.3 & & 2⿺⿻一𠃋十 & -nll \\
\hline $\begin{array}{l}\text { Vacuum pump with variable } \\
\text { speed controls: Yes }\end{array}$ & 0.2 & & & +1 \\
\hline $\begin{array}{l}\text { Pre-cool milk before storage } \\
\text { tank: Yes }\end{array}$ & 0.2 & & inl & II \\
\hline $\begin{array}{l}\text { Accurate milk tank thermostat: } \\
\text { Yes }\end{array}$ & 0.2 & & 2 & 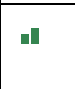 \\
\hline $\begin{array}{l}\text { Refrigeration condenser } \\
\text { sufficiently ventilated: Yes }\end{array}$ & 0.2 & & 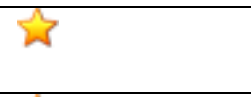 & 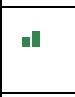 \\
\hline Straw chopping: No & 0.1 & & ह3 & |ll \\
\hline $\begin{array}{l}\text { Maximum traction efficiency } \\
\text { obtained }(10-15 \% \text { wheel slip): } \\
\text { Yes }\end{array}$ & 0.1 & & 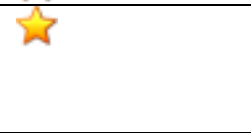 & III \\
\hline $\begin{array}{l}\text { Improved milk tank and pipe } \\
\text { insulation: Yes }\end{array}$ & 0.1 & & sh & + \\
\hline $\begin{array}{l}\text { Direct expansion refrigeration } \\
\text { bulk tank: Yes }\end{array}$ & 0.1 & & b? & 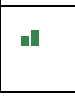 \\
\hline
\end{tabular}

Icon key

A Potential negative environmental impact

Relative capital cost

Potential positive environmental impact

Relative annual cost (benefit)

nll Data quality (DQ): Low • , Moderate nll , High nnll

Relative annual cost (burden) 


\subsection{Discussion and conclusions}

\subsection{Carbon calculators in context}

Agriculture alongside other industry sectors has a role to play to help reduce emissions and lower atmospheric concentrations of greenhouse gases. This needs to be achieved within the context of sustainable food production and consumption which encompasses economically viable farming and national and global food security. Therefore tools which help the industry, and those who regulate it, identify options to reduce emissions on a cost benefit basis are essential.

The need for a tool to calculate carbon emissions at the farm level is debateable. Simply knowing the amount of carbon may be interesting and may raise awareness, but it does not necessarily change or drive practices in more sustainable directions. What is perhaps more important is to understand how practices on the farm could be improved to reduce emissions with minimal financial or environmental cost (and preferably financial and environmental benefits) - this would be a more pragmatic tool. However, in the broader context of the supply chain, and taking a life cycle perspective, there can be demands to know the amount of carbon from production processes, including the farm level. For example, Pepsico UK undertook a carbon audit of each stage of the production process of their Walkers crisps product (IEMA, 2009). In so doing, Pepsico UK discovered that $59 \%$ of the carbon footprint was outside of their direct control, with $42 \%$ being at the farm level. Therefore, as part of the plan to reduce the carbon footprint, they had to work with suppliers, including farmers, to find ways of lowering carbon emissions, and consequently Pepsico UK retained the carbon reduction label on the end product. Therefore the ability to calculate carbon emissions at the farm level can be important to support such processes.

There are strategic perspectives which are not captured within farm level carbon calculators. For example, the growing of biofuel crops on farms has the potential to displace fossil fuels and thus reduce net contributions to atmospheric GHGs. The use of biofuels on farms is a mitigation option within the IMPACCT software, but the commercial production of biofuels, and their displacement of fossil fuels used by society, is not captured within the model. This is a strategic issue, as the growing of biofuels has the potential to displace food production (Rathmann et al., 2010), and consequently food production may shift to other places in the world where GHG emissions are higher. This is not something that can be easily captured in a farm level tool. However, there may be scope to benchmark the carbon emission of a farm in order to partly account for such issues. If it is possible to determine that a farms product has high or low emissions (per tonne) compared to similar products grown elsewhere, it may be possible to determine whether GHG emissions overall may increase or decrease if production ceased on that farm. For example, if a product has a relatively low carbon footprint, then displacement of production to farms with a higher footprint could increase emissions for that product overall, assuming there is no increase or decrease in demand for that commodity. Such decisions are strategic in nature and thus are for policy makers to pursue, although awareness of the wider impacts of the decisions we all make could be a positive driver.

The IMPACCT model and software has aimed to provide an integrated perspective to allow users to identify potential mitigation options and assess the various environmental and economic costs and benefits. This reflects the advances that have been made in recent years that have enabled a shift from problem quantification to solution identification, and the assessment of costs and benefits of potential mitigation options (Committee on Climate Change, 2010a\&b; Franks and Hadingham, 2012; MacLeod et al., 2010). Carbon calculators that only calculate emissions are useful, in that they quantify the key sources of emissions. However, these tools need to evolve and take a step into solution identification, and thus should be aiming to provide users with decision support on options and choices on how to reduce those emissions in the most cost effective way (Hockman and Carberry, 2011; McIntosh et al., 2011). 


\subsection{Limitations of the IMPACCT model}

The feedback from users across Europe (22 farms in 7 Member States) who have tested and used IMPACCT was generally positive and it was considered simple to use, with effective use of charts and icons to summarise data. The only negative feedback related to the number of options available to describe farming practices, which was considered to be too limited, so it was not possible to capture the detail of some farming systems. This highlights that the IMPACCT software is very much a prototype and as such it does have some limitations. These include:

- Firstly, the underlying data within the core database is a 'first edition' and does not cover all farming enterprises and practice variations, so it could be improved and refined.

- Secondly, sequestration data are somewhat lacking compared to the amount of data on emissions due to the amount of data that is generally available and the uncertainty associated with sequestration processes, such as sequestration rates and carbon equilibriums. However, there is still scope to improve the sequestration data within the core database and how this is used within the IMPACCT software.

- Thirdly, the data and information on other environmental impacts and economics could both be improved. Additional environmental impacts could be added, and there is also potential to quantify these impacts in the same way as greenhouse gas emissions (this was beyond scope of this study). Economic data was particularly problematic, being scarce, highly qualitative and highly variable across Europe. The core database is designed to handle economic data in the same way as emissions, but due to data problems an alternative means of expressing economic impacts was developed. However, there is scope in the future to implement a more advanced economic assessment should the data improve.

- Fourthly, although the data quality score provides a good 'barometer' of the quality of the evidence that has been used as a basis for the calculations, it does not necessarily represent the uncertainty and variability. For example some aspects, such as carbon sequestration, are uncertain and a range of values can exist. This range will have been taken into account in the data quality score, but perhaps what should be done would be to express a range (e.g. from best to worse case) within the end results.

- Finally, the IMPACCT software interface is also very much a prototype and could be improved. The general functionality and simplicity of the interface has been praised by those who have used it and most have found it easy to use. However, some compromises were made to develop the software in a relatively short space of time. Additionally, the speed of the calculation and data processing routines are sometimes unacceptably slow, particularly when there are a lot of farm components and mitigation options, so this is something that would need to be addressed in any future developments.

\subsection{Conclusions}

Despite the limitations outlined above, it is considered that the IMPACCT software presents some useful concepts for carbon calculators for them to be advanced in the future. It focuses users towards those practices that likely to be most effective at reducing emissions and the cost-benefit of those practices with respect to any likely economic impacts and other environmental impacts. This could be further enhanced with links to additional information (such as websites or other models) to help users undertake a more detailed assessment of the implications implementing specific mitigation options on their farm. As such the tool could become a powerful means of providing targeted advice and guidance as part of a knowledge transfer programme. However, it is important that it is part of a broader knowledge transfer programme. An integrated suite of guidance, tools and advice is required delivered via different media in order to ensure that different end users can access the knowledge required to deliver sustainable farming and food. 


\section{References}

Brentrup, F., Küsters, J., Kuhlmann, H. and Lammel, J. (2004), "Environmental impact assessment of agricultural production systems using the life cycle assessment methodology I. Theoretical concept of a LCA method tailored to crop production", European Journal of Agronomy, Vol. 20, pp. 247-264.

BSI (2008), "PAS 2050:2008. Specification for the assessment of the life cycle greenhouse gas emissions of goods and services. Publicly Available Specification", British Standards Institute, Carbon Trust, Department for Environment, Food and Rural Affairs (Defra). ISBN 978058050978 0, British Standards Institute (BSI), London.

CALU (2007), "Managing Energy and Carbon. The farmers guide to energy audits", Centre for Alternative Land Use (CALU), University of Bangor, Wales.

CFF (2010), "The CFF carbon calculator", Carbon Friendly Food (CFF), available at: http://www.cffcarboncalculator.org.uk/ (accessed 25 September 2012).

CCaLC (2011), "Carbon Calculations over the Life Cycle of Industrial Activities", http://www.ccalc.org.uk/index.php (accessed 25 September 2012).

Cederberg, C. and Stadig, S. (2003), "System expansion and allocation in life cycle assessment of milk and beef production", International Journal of Life Cycle Assessment Vol. 8 No. 6, pp. 350-356.

Chambers, B.J., Lord, E.I., Nicholson, F.A. and Smith, K.A. (1999), "Predicting nitrogen availability and losses following application of organic manure to arable land: MANNER", Soil Use and Management, Vol. 15, pp. 137-143.

CLA (2012), "CALM - Carbon Accounting for Land Managers tool", Country Land and Business Association (CLA), available at: http://www.cla.org.uk/Policy Work/CALM Calculator/ (accessed 25 September 2012).

Committee on Climate Change (2010a), "Meeting Carbon Budgets - ensuring a low-carbon recovery", 2nd Progress Report to Parliament, Committee on Climate Change, June 2010, London.

Committee on Climate Change (2010b), "The Fourth Carbon Budget. Reducing emissions through the 2020s", Crown Copyright, UK. Committee on Climate Change, December 2010, London.

CPLAN (2012), "The CPLAN carbon calculator", available at: http://www2.cplan.org.uk/ (accessed 25 September 2012).

Dawson, J.J.C. and Smith, P. (2007), "Carbon losses from soil and its consequences for landuse management", Science of the Total Environment, Vol. 382, pp. 165-190.

DECC (2012), "Agriculture. GHG Inventory summary Factsheet", Department for Energy and Climate Change (DECC), 30 June 2012, London.

Defra (2005), "The UK Government Sustainable Development Strategy", Presented to Parliament by the Secretary of State for Environment, Food and Rural Affairs by Command of Her Majesty March 2005, Cm 6467, ISBN 0-10-164672-0, London.

Dobbie, K.E. and Smith, K.A. (2003), "Nitrous oxide emission factors for agricultural soils in Great Britain: the impact of soil water-filled pore space and other controlling variables", Global Change Biology, Vol. 9, pp. 204-218.

Dyson, K. E., Thomson, A. M., Mobbs, D. C., Milne, R., Skiba, U., Clark, A., Levy, P. E., Jones, S. K., Billett, M. F., Dinsmore, K. J., van Oijen, M., Ostle, N., Foereid, B., Smith, P., Matthews, R. W., Mackie, E., Bellamy, P., Rivas-Casado, M., Jordan, C., Higgins, A., Tomlinson, R. W., Grace, J., Parrish, P., Williams, M., Clement, R., Moncrieff, J. and Manning, A. (2009), "Inventory and projections of UK emissions by sources and removals by sinks due to land use, land use change and forestry", Ed: K.E. Dyson. Annual Report, July 2009. Department for the Environment, Food and Rural Affairs Climate, Energy and Ozone: Science and Analysis Division Contract GA01088, London.

European Commission (1985), "Commission Decision of 7 June 1985 establishing a Community typology for agricultural holdings", Official Journal L 220, 17/08/1985 P. 0001 - 0032.

European Commission (2009), "The role of European agriculture in climate change mitigation", European Commission Staff Working Document, 23/7/2009.

Franks, J.R. and Hadingham, B. (2012), "Reducing greenhouse gas emissions from agriculture: Avoiding trivial solutions to a global problem", Land Use Policy, Vol. 29 No. 4, pp. 727-736. 
Girardin, P., Bockstaller, C. and van der Werf, H.M.G. (2000), "Assessment of potential impacts of agricultural practices on the environment: the AGRO*ECO method", Environmental Impact Assessment Review, Vol. 20, pp. 227-239.

GREENERGY (2008), "Energy optimisation in European greenhouses. Deliverable 10: Software usability tests report", Wageningen University, January 2008.

Harvey, M. and Pilgrim, S. (2010), "Competition for land: food and energy", Paper prepared for UK Government Foresight Project on Global Food and Farming Futures, UK Government, London.

Hillier, J., Walter, C., Malin, D., Garcia-Suazer, T., Milia-i-Canals, L. and Smith, P. (2011), "A farm-focused calculator for emissions from crop and livestock production", Environmental Modelling and Software, Vol. 26, pp. 1070-1078.

Hockman, Z. and Carberry, P.S. (2011), "Emerging consensus on desirable characteristics of tools to support farmers' management of climate risk in Australia", Agricultural Systems, Vol. 104, 441-450.

HGCA (2006), "Green Fuel you can trust: Developing accreditation for bioethanol in the UK", Home Grown Cereals Authority (HGCA), London.

IEMA (2009), "From potato to packet - measuring and reducing the carbon content of a Walkers crisp", IEMA Practitioner Volume 14 - Supporting Information, Institute of Environmental Management and Assessment (IEMA), Lincoln, UK.

IPCC (2006), "2006 Guidelines for National Greenhouse Gas Inventories. Intergovernmental Panel on Climate Change", Prepared by the National Greenhouse Gas Inventories Programme, Eggleston H.S., Buendia L., Miwa.

Johnston, A.E. (2008), "Resource or waste: the reality of nutrient cycling to land", The International Fertiliser Society Proceedings, Vol. 630.

King, J.A., Bradley, R.I., Harrison, R. and Carter, A.D. (2004), "Carbon sequestration and saving potential associated with changes to the management of agricultural soils in England", Soil Use and Management, Vol. 20, pp. 394-402.

Körner, O., Warner, D.J., Tzilivakis, J., Eveleens, B. and Heuvelink, E. (2007), "Decision support for optimising energy consumption in European greenhouses", GREENSYS 2007 organised by the International Society for Horticultural Science, Naples, Italy, 4-5th October 2007.

Lewis, K.A., Brown, C.D., Hart, A. Tzilivakis, J. (2003), "P-EMA: overview and application of a software system designed to assess the environmental risks of agricultural pesticides", Agronomie, Vol. 23, pp. 85-96.

Lewis, K.A., Green, A. and Tzilivakis, J. (2007), "Development of an Improved Pesticide properties Database for Risk Assessment", Proceedings of the European Federation for IT in Agriculture (EFITA) conference 2-5 July 2007, Glasgow.

MacLeod, M., Moran, D., Eory, V., Rees, R.M., Barnes, A., Topp, C.F.E., Ball, B., Hoad, S., Wall, E., McVittie, A., Pajot, G., Matthews, R., Smith, P. and Moxey, A. (2010), "Developing greenhouse gas marginal abatement cost curves for agricultural emissions from crops and soils in the UK", Agricultural Systems, Vol. 103, pp. 198-209.

McGuffey R.K., Richardson, L.F. and Wilkinson, J.I.D. (2003), "Ionosphores for dairy cattle: Current status and future outlook", Journal of Dairy Science, Vol. 84(E. Supplement), pp. E194-E203.

McIntosh, B.S., Ascough II, J.C., Twery, M., Chewe, J., Elmahdi, A., Haase, D., Harou, J.J., Hepting, D., Cuddy, S., Jakeman, A.J., Chen, S., Kassahun, A., Lautenbach, S., Matthews, K., Merritt, W., Quinnm, N.W.T., Rodriguez-Roda, I., Sieber, S., Stavenga, M., Sulis, A., Ticehurst, J., Volk, M., Wrobel, M., van Delden, H., El-Sawah, S., Rizzoli, A. and Voinov, A. 2011. Environmental decision support systems (EDSS) development - Challenges and best practices. Environmental Modelling and Software 26, 1389-1402.McPhee, M.J., Edwards, C., Meckiff, .J, Ballie, J., Schneider, D., Arnott, P., Cowie, A., Savage, D., Lamb, D., Guppy, C, McCorkell, B and Hegarty, R. (2010), "Estimating on-farm methane emissions for sheep production on the Northern Tablelands: establishment of demonstration site", Australian Farm Business Management Journal, Vol. 7 No. 2, pp. 85-94.

McPhee, M.J., Edwards, C., Meckiff, .J, Ballie, J., Schneider, D., Arnott, P., Cowie, A., Savage, D., Lamb, D., Guppy, C, McCorkell, B and Hegarty, R. (2010), "Estimating on-farm methane emissions for sheep production on the Northern Tablelands: establishment of demonstration site", Australian Farm Business Management Journal, Vol. 7 No. 2, pp. 85-94. 
Milà i Canals, L., Cowell, S.J., Sim, S. and Basson, L. (2007), "Comparing domestic versus imported apples: a focus on energy use", Environmental Science Pollution Research, Vol. 14 , pp. 338-344

NRCS (2007), "The Comet-VR Carbon Sequestration Tool", Natural Resources Conservation Service (NRCS), available at: http://www.cometvr.colostate.edu/about/ (accessed 25 September 2012).

Ostle, N.J., Levy, P.E., Evans, C.D. and Smith, P. (2009), "UK land use and soil carbon sequestration", Land Use Policy, Vol. 26, pp. S274-S283.

Petchey, P., D'Arcy, B. and Frost, A. (Eds.) (1995), "Diffuse Pollution and Agriculture", Proceedings of a conference held in Edinburgh, 12-14 April 1995. Scottish Agricultural College (SAC).

Pretty, J.N., Brett, C., Gee, D., Hine, R.E., Mason, C.F., Morison, J.I.L., Raven, H., Rayment, M.D. and van der Bijl, G. (2000), "An assessment of the total external costs of UK agriculture", Agricultural Systems, Vol. 65 No. 2, pp. 113-136.

Pretty, J. N., Ball, A. S., Lang, T and Morison, J. I. L. (2005), "Farm costs and food miles: An assessment of the full cost of the UK weekly food basket", Food Policy, Vol. 30, pp. 1-19.

Rathmann, R., Azklo, A. and Schaeffer, R. (2010), Land use competition for production of food and liquid biofuels: An analysis of the arguments in the current debate, Renewable Energy, Vol. 35, pp. 14-22.

Renting, H., Rossing, W.A.H., Groot, J.C.J., Van der Ploeg, J.D., Laurent, C., Perraud, D., Stobbelaar, D.J., Van Ittersum, M.K. (2009), "Exploring multifunctional agriculture. A review of conceptual approaches and prospects for an integrative transitional framework", Journal of Environmental Management, Vol. 90, pp. S112-S123.

Skinner, J.A., Lewis, K.A., Bardon, K.S., Tucker, P., Catt, J.A. and Chambers, B.J. (1997), "An Overview of the Environmental Impact of Agriculture in the U.K", Journal of Environmental Management, Vol. 50, pp. 111-128.

Smith, J.U., Bradbury, N.J. and Addiscott, T.M. (1996), "SUNDIAL: A PC-based system for simulating nitrogen dynamics in arable land", Agronomy Journal, Vol. 88, pp. 38-43.

Smith, P., Martino, D., Cai, Z., Gwary, D., Janzen, H., Kumar, P., McCarl, B., Ogle, S., O'Mara, F., Rice, C., Scholes, B., and Sirotenko, O. (2008), "Greenhouse gas mitigation in agriculture", Philosophical Transactions of the Royal Society, Vol. B 363, pp. 67-79.

Solagro (2012), "European carbon calculator to promote low carbon farming practices", available at: http://www.solagro.org/site/476.html (accessed 25 September 2012).

Solomon, S., Quin, D., Manning, M., Chen, Z., Marquis, M., Averyt, K.B., Tignor, M. and Miller, H. L. (Eds.) (2007), "Climate Change 2007: The Physical Science Basis", Contribution of Working Group 1 to the Fourth Assessment Report of the Intergovernmental Panel on Climate Change (IPCC), Chapter 11, Regional Climate Projections, Cambridge University Press, Cambridge, UK.

Stern, N. (2006), "The Economics of Climate Change. The Stern Review", Cambridge University Press, ISBN: 9780521700801, p712.

Tedeschi, L.O., Fox, D.G. and Tylutki, T.P. (2003), "Potential environmental benefits of ionophores in ruminant diets", Journal of Environmental Quality, Vol. 32, pp. 1591-1602

Thomas, C. (2004), "Feed into Milk (FiM): a New Applied Feeding System for Dairy Cows", Nottingham University Press, UK.

Tzilivakis, J., Lewis, K.A., Warner, D.J. and Green, A. (2009), "Assessment of Reduction in Environmental Burdens through Targeted Measures compared with Whole Farm Approaches in Cropping and Livestock Systems", Final report for project IF0131 prepared for the Department for Environment, Food and Rural Affairs (Defra), London.

Tzilivakis, J., Lewis, K.A., Green, A. and Warner, D.J. (2011), "A novel technique for identifying environmental outcomes from agricultural practices", Impact Assessment and Project Appraisal, Vol. 29 No. 1, pp. 2-10.

UN (1998), "Kyoto Protocol to the United Nations Framework Convention on Climate Change", United Nations.

Van Huylenbroeck, G. and Durand, G. (Eds.) (2003), "Multifunctional Agriculture: A New Paradigm for European Agriculture", Ashgate Publishing, Burlington, p239.

Watkiss, P. (2009), "Comparative life-cycle assessment of food commodities procured for UK consumption through a diversity of supply chains", Report prepared for Department for Environment, Food and Rural Affairs (Defra), Project FO0103, by Watkiss Associates, July 2009. 
Williams, A.G., Audsley, E. and Sandars, D.L. (2009), "Environmental Burdens of Agricultural and Horticultural Commodity Production - LCA (IS0205) version 3", Cranfield University, UK.

Williams, A.G., Audsley, E. and Sandars, D.L. (2006), "Determining the environmental burdens and resource use in the production of agricultural and horticultural commodities", Main Report. Defra Research Project IS0205. Bedford: Cranfield University and Defra.

Withers, P.J.A. and Lord, E.I. (2002), "Agricultural nutrient inputs to rivers and groundwaters in the UK: policy, environmental management and research needs", The Science of the Total Environment, Vol. 282-283, pp. 9-24.

WRI (2011), "The Greenhouse Gas Protocol: a corporate accounting and reporting standard", World Resources Institute (WRI), available at: http://www.wbcsd.org/web/publications/ghgprotocol.pdf (accessed 25 September 2012). 